\title{
Duodenal pseudomelanosis (pseudomelanosis duodeni): a rare endoscopic finding
}

\author{
Aloísio Felipe-Silva ${ }^{a}$ Fernando Peixoto Ferraz de Campos $^{b}$, José Guilherme Nogueira da Silva ${ }^{c}$
}

Felipe-Silva A, Campos FPF, Silva JGN. Duodenal pseudomelanosis (pseudomelanosis duodeni): a rare endoscopic finding. Autopsy Case Rep [Internet]. 2011;1(4):39-44. http://dx.doi.org/10.4322/acr.2011.015

\section{ABSTRACT}

Duodenal pseudomelanosis (or pseudomelanosis duodeni) is a rare benign condition characterized by black-brown speckled pigmentation of the duodenal mucosa. Collections of pigment-laden macrophages are found in the tips of duodenal villi. The pigment is thought to be mostly composed of ferrous sulfide. Histochemichal stains for iron (Perl's prussian blue) or melanin (MassonFontana) may be positive, but are usually negative or unpredictable. Duodenal pseudomelanosis occurs predominantly in middle-aged to old adults and more commonly in females. It is associated with chronic renal failure, arterial hypertension, diabetes mellitus and gastrointestinal bleeding. Medications such as ferrous sulfate, hydralazine, propranolol, hydrochlorothiazide and furosemide are thought to play a role as well. We report a case of a 86-year-old female who presented with a history of watery diarrhea and melena. The patient had a history of high blood pressure and ischemic stroke episodes. She was on multiple medication including hidralazine, captopril, hydrochlorthiazide and aspirin. She was dehydrated, her blood pressure was $96 \times 60 \mathrm{mmHg}$ and neurologic examination showed complete left hemiplegia with central VII nerve palsy. Laboratory tests showed normal serum electrolytes and renal function. Hemoglobin level was $10.7 \mathrm{~g} \%$. An upper endoscopy showed multiple diminutive black spots throughout the distal duodenal bulb and second portion. Histology showed multiple foci of a brown-black granular pigment inside macrophages within the tips of the villi (pseudomelanosis). Stains for iron and melanin were negative. She was treated with omeprazol, parenteral fluid replacement with saline and partial fasting. After complete recovery she was discharged for ambulatory follow up.

Keywords: Melanosis; Pigmentation; Duodenum; Renal insufficiency; Hypertension; Iron.

\section{CASE REPORT}

A 86-year-old female presented with a history of watery diarrhea for the last three days. Her daughter, who was in charge of her care, noticed that the feces became progressively more liquid and dark colored resembling melena, sometimes with bloody traces. She denied abdominal pain, fever or vomiting. This was the second similar episode within the last month. The patient had a history of high blood pressure and three distinct ischemic stroke episodes, the latter two years ago, since when she became bedridden. The patient was on multiple medication including hidralazine, captopril, hydrochlorthiazide and aspirin.

\footnotetext{
${ }^{a}$ Anatomic Pathology Service - Hospital Universitário, Universidade de São Paulo, São Paulo/SP - Brazil.

${ }^{\text {b }}$ Department of Internal Medicine - Hospital Universitário, Universidade de São Paulo, São Paulo/SP - Brazil.

c Endoscopy Service - Hospital Universitário, Universidade de São Paulo, São Paulo/SP - Brazil.
} 
Physical examination revealed a conscious patient, slightly lethargic, with a slurred speech (since the previous stroke), dehidrated. Her blood pressure was $96 \times 60 \mathrm{mmHg}$ and pulse was $96 \mathrm{bpm}$. Neurologic examination showed complete left hemiplegia with central VII nerve palsy.

Laboratory tests showed normal serum electrolytes and renal function. On blood cell count the hemoglobin was $10.7 \mathrm{~g} \%$ with normal mean corpuscular volume and red cell distribution width, leukocytes and platelets were within the normal range.
Because of the suspicion of gastrointestinal bleeding an upper endoscopy was performed. Endoscopy showed esophageal hernia, Los Angeles A distal esophagitis, enantematous gastritis and gastric angiodysplasia without any evidence of bleeding. Duodenal mucosa was lightly pale with multiple diminutive black spots throughout the distal bulb and second portion (Figure 1). Duodenal biopsies were taken.

Histological examination showed multiple foci of a brown-black granular pigment, mostly inside macrophages within the tips of the villi (Figure 2). Perls' prussian blue stain for iron and Masson-Fontana
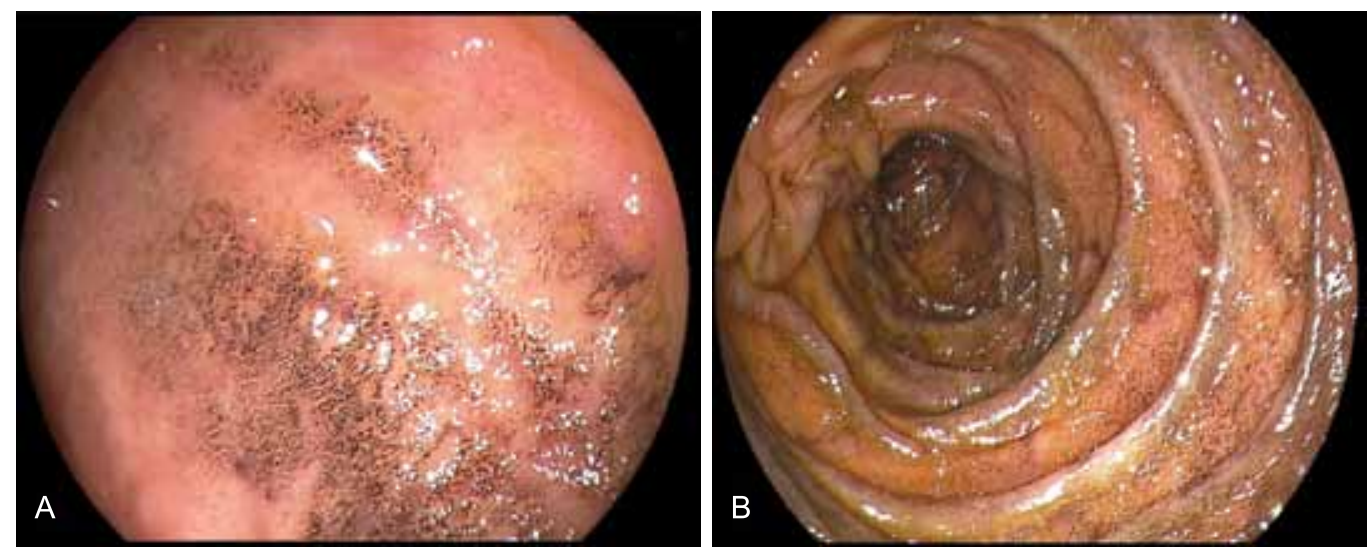

Figure 1 - Endoscopic view of duodenal bulb (A) and second portion (B), showing multiple and speckled black spots.
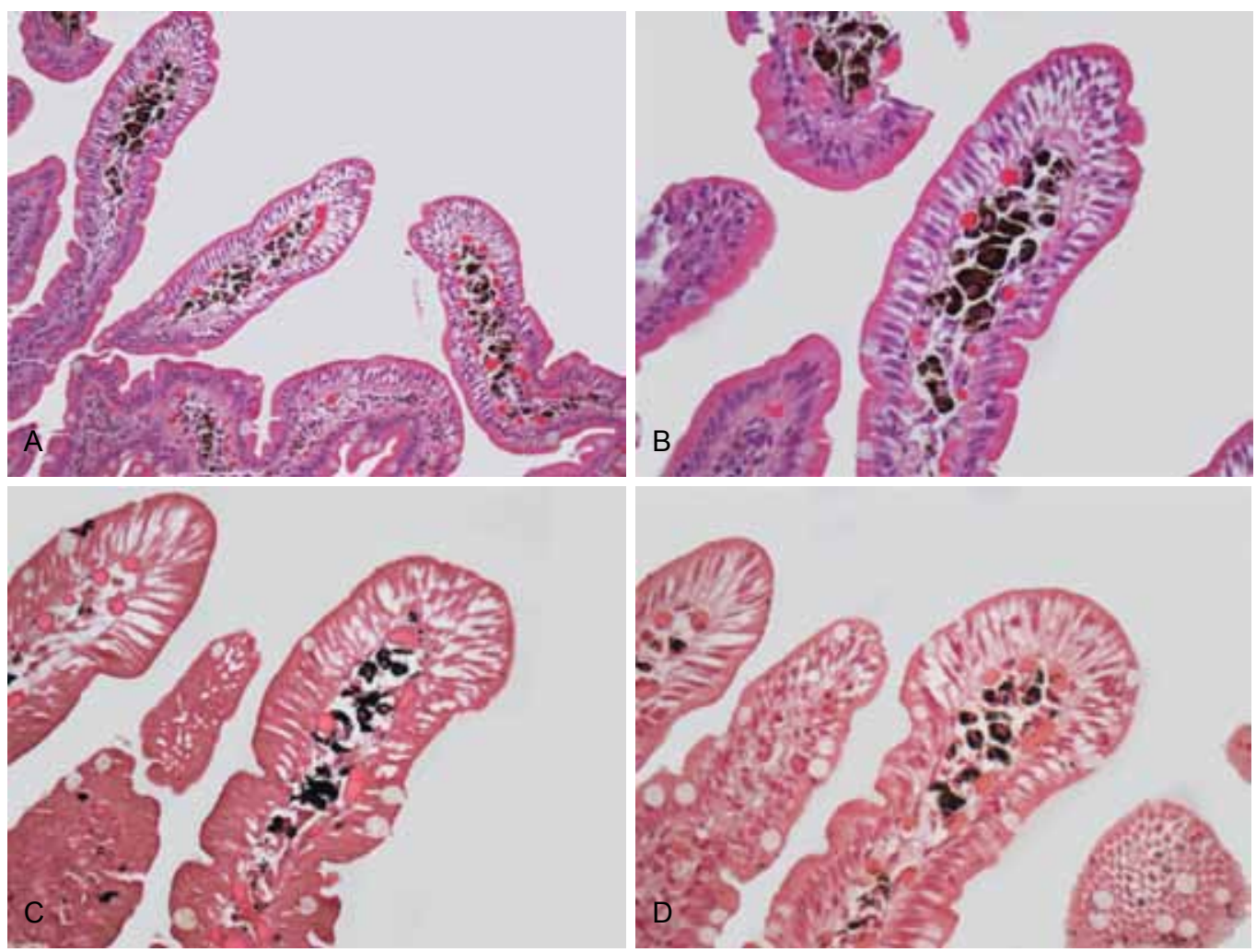

Figure 2 - A, B- Multiple foci of a brown-black granular pigment inside macrophages within the tips of the duodenal villi (H\&E-200x, 400x). C- Masson-Fontana and D- Perls Prussian blue stain were negative. There was no change in the black-brown nature of the original pigment (400x) 
stain for melanin were negative. The black-brown color seen in the special stains slides were interpreted as intrinsic pigmentation from pseudomelanosis. A diagnosis or duodenal pseudomelanosis was rendered.

The recent change in bowel habits and hematochezia was interpreted as possible manifestation of ischemic colitis or colonic angiodysplasia, and because of the patient's clinical status she was not submitted to a colonoscopy. She was treated with omeprazol, parenteral fluid replacement with saline and partial fasting. After complete recovery she was discharged for ambulatory follow up.

\section{DISCUSSION}

Duodenal pseudomelanosis (or pseudomelanosis duodeni) is a rare benign condition first described by Bisordi \& Kleinman in $1976^{1}$ as "melanosis duodeni", since the real nature of the black-brown pigmentation of the mucosa had not been further investigated. Originally the pigment was thought to be derived from melanin ${ }^{1-4}$ but it was later demonstrated to be mainly ferrous sulfide ${ }^{5-7}$ and distinct from melanin, hemossiderin ${ }^{8}$ or lipofuscin.

This condition is characterized by collections of pigment-laden macrophages in the tips of duodenal villi, which may be detected at endoscopy as dark spots. Several case reports and a few case series have been described in the literature. ${ }^{9-35}$ The largest case series included 17 adult patients. ${ }^{36}$

Duodenal pseudomelanosis occurs predominantly in middle-aged to old adults and more commonly in females (1.2-2:1). ${ }^{14,36}$ Pediatric cases have been reported. ${ }^{22,37}$ There is a strong association with chronic renal failure, arterial hypertension, diabetes mellitus and the use of medications such as ferrous sulfate, hydralazine, propranolol, hydrochlorothiazide and furosemide. ${ }^{6,36}$ Some cases have been associated with gastrointestinal bleeding. ${ }^{38}$

As this patient completely recovered from diarrhea and hematochezia and also because of her clinical status, no further investigation by invasive methods was proposed. Apparently there is no correlation between duodenal pseudomelanosis and her symptoms, unless an occult previous upper gastrointestinal bleeding could not be detected at endoscopy. Alternatively, her symptoms were interpreted as a possible manifestation of ischemic colitis or colonic angiodysplasia.

At upper endoscopy the duodenum mucosa is speckled with multiple discrete, flat, small dark spots (usually $<2 \mathrm{~mm}$ ), mainly in the proximal portions (bulb and second portion). 2,3,19 Occasionally the brownishblack spots may be seen in the mucosa of stomach, jejunum or ileum. ${ }^{29,39,40}$

The diagnosis is usually made by mucosal biopsies. A collection of macrophages packed with a characteristic brown-black granular pigment is seen within the lamina propria of the villi on routine optical microscopy. Black-brown pigment may also be seen in epithelial cells or extracellular matrix. ${ }^{2,3,19,38}$ Histochemichal stains for iron (Perl's prussian blue) or melanin (Masson-Fontana) may be positive, but are usually negative or unpredictable..$^{6,36}$

On electron microscopy, angular crystalline plates, or sometimes rounded or irregularly shaped membrane bound, electron dense structures can be seen, occasionally contained within lysosomal bodies. .,9, $^{6,38}$

Electron-probe $\mathrm{X}$-ray analysis have demonstrated a high content of iron and variable contents of sulfur in the pigment granules. ${ }^{5,8,10,16}$ The pigment in duodenal pseudomelanosis has now been shown to consist largely of iron sulfide $(\mathrm{FeS})^{13,41}$, with trace amounts of other elements like calcium, potassium, aluminum, magnesium, and silica. ${ }^{5}$

The detection of iron by histochemistry is variable in duodenal pseudomelanosis. ${ }^{5,10,36}$ Iron sulfide, which is formed by ferrous iron $\left(\mathrm{Fe}^{2+}\right)$, is known to give a negative reaction with Perl's prussian blue once this method mainly stains ferric iron $\left(\mathrm{Fe}^{3+}\right){ }^{42}$ Furthermore, iron sulfide may spontaneously become auto-oxidized to iron oxide, leading to variations in the iron staining properties even in the same patient. ${ }^{5,10}$ Masson-Fontana stain, which is commonly used for the identification of melanin in routine histopathology, may also be positive in duodenal pseudomelanosis; however, it is not specific because other reducing substances, including ferrous iron, can also stain by this method. ${ }^{6}$

It has been proposed that the coupling of iron and sulfur in iron sulfide leads to difficulty in iron transport and results in accumulation of these crystals in macrophages of the duodenal lamina propria. ${ }^{16}$ Interestingly, the proximal duodenum is 
also the site of maximal iron absorption in normal physiology. However, the source of sulfur is not clear. It is noted that most of patients with duodenal pseudomelanosis have received antihypertensive medications. Therefore, some authors have proposed that antihypertensive medications containing a sulfur moiety such as furosemide and hydrochlorothiazide could be this source. ${ }^{17,22}$ Our patient was taking hydrochlorothiazide; however, several patients with duodenal pseudomelanosis were reported to be on medications that do not contain sulfur moieties. ${ }^{36}$

Microscopic diagnosis of duodenal pseudomelanosis is quite straightforward. However, endoscopic and histopathological differential diagnoses include metastatic melanoma (and its threatening manifestation of panenteric melanosis ${ }^{43}$ ) and other pigmentations including exogenous ingested substances like charcoal. ${ }^{44}$

The precise diagnostic and prognostic significance of duodenal pseudomelanosis is unknown. According to current knowledge, it seems to be a sign of the local microenvironment and not a disease itself. ${ }^{13,18}$ Duodenal pseudomelanosis has not been documented to cause local complications like fibrosis or strictures. No specific therapeutic or follow-up protocol is recommended. ${ }^{36}$ Resolution after discontinuation of oral iron therapy was described in a patient with $B$ thalassemia, chronic renal insufficiency, diabetes and hypertension. ${ }^{45}$

\section{ACKNOWLEDGMENTS}

We are grateful to Rosa Maria C. Zanardi for the technical support on the visual work.

\section{REFERENCES}

1. Bisordi WM, Kleinman MS. Melanosis duodeni. Gastrointest Endosc. 1976;23(1):37-8. http://dx.doi.org/10.1016/S00165107(76)73576-4

2. Breslaw L. Melanosis of the duodenal mucosa. Gastrointest Endosc. 1980;26(2):45-6. http://dx.doi.org/10.1016/S00165107(80)73267-4

3. Ganju S, Adomavicius J, Salgia K, Steigmann F. The endoscopic picture of melanosis in the duodenum. Gastrointest Endosc. 1980;26(2):44-5. http://dx.doi.org/10.1016/S00165107(80)73266-2
4. Castellano G, Canga F, Lopez I, et al. Pseudomelanosis of the duodenum. Endoscopic, histologic, and ultrastructural study of a case. J Clin Gastroenterol. 1988;10(2):150-4. PMid:2458403. http://dx.doi.org/10.1097/00004836198804000-00009

5. Pounder DJ. The pigment of duodenal melanosis is ferrous sulfide. Gastrointest Endosc. 1983;29(3):257. http://dx.doi. org/10.1016/S0016-5107(83)72614-3

6. Kang JY, Wu AY, Chia JL, Wee A, Sutherland IH, Hori R. Clinical and ultrastructural studies in duodenal pseudomelanosis. Gut. 1987;28(12):1673-81. PMid:3428696. PMCid:1433926. http://dx.doi.org/10.1136/gut.28.12.1673

7. Rex DK, Jersild Junior RA. Further characterization of the pigment in pseudomelanosis duodeni in three patients. Gastroenterology. 1988;95(1):177-82. PMid:3371613.

8. Steckman M, Bozymski EM. Hemosiderosis of the duodenum. Gastrointest Endosc. 1983;29(4):326-7. http://dx.doi. org/10.1016/S0016-5107(83)72653-2

9. Cowen ML, Humphries TJ. Pseudomelanosis of the duodenum. Endoscopic and histologic observations on a unique case of pigmentation in the duodenum. Gastrointest Endosc. 1980;26(3):107-8. http://dx.doi.org/10.1016/ S0016-5107(80)73289-3

10. Yamase $H$, Norris M, Gillies C. Pseudomelanosis duodeni: a clinicopathologic entity. Gastrointest Endosc. 1985;31(2):836. http://dx.doi.org/10.1016/S0016-5107(85)72001-9

11. Gupta TP, Weinstock JV. Duodenal pseudomelanosis associated with chronic renal failure. Gastrointest Endosc. 1986;32(5):358-60. http://dx.doi.org/10.1016/ S0016-5107(86)71887-7

12. Lee HH, O'Donnell DB, Keren DF. Characteristics of melanosis duodeni: incorporation of endoscopy, pathology, and etiology. Endoscopy. 1987;19(3):107-9. PMid:3608917

13. West B. Pseudomelanosis duodeni. J Clin Gastroenterol. 1988; 10(2):127-9. http://dx.doi.org/10.1097/00004836-19880400000003

14. Lin HJ, Tsay SH, Chiang $\mathrm{H}$, et al. Pseudomelanosis duodeni. Case report and review of literature. J Clin Gastroenterol. 1988;10(2):155-9. PMid:2458404. http:// dx.doi.org/10.1097/00004836-198804000-00010

15. Kuo YC, Wu CS. Duodenal melanosis. J Clin Gastroenterol. 1988;10(2):160-4. PMid:2458405. http:// dx.doi.org/10.1097/00004836-198804000-00011

16. Fernando SS. Pseudomelanosis duodeni: a case report with electron-probe X-ray analysis. Pathology. 1990;22(3):169-72. PMid:1700852. http://dx.doi.org/10.3109/00313029009063559

17. Leong S. Pseudomelanosis duodeni and the controversial pigment--a clinical study of 4 cases. Ann Acad Med Singapore. 1992;21(3):394-8. PMid:1341423. 
18. Minocha A, Fearneyhough PK, McClave SA, Parker Junior JC. Melanin-like pigmentation of the duodenum. Am J Gastroenterol. 1995;90(6):1018-20. PMid:7771401.

19. eL-Newihi HM, Lynch CA, Mihas AA. Case reports: pseudomelanosis duodeni: association with systemic hypertension. Am J Med Sci. 1995;310(3):111-4. PMid:7668306.

20. Wang K, Lin HJ, Perng CL, et al. Pseudomelanosis duodeni: report of eight cases. J Formos Med Assoc. 1995;94(10):6324. PMid:8527967.

21. Nishimura $Y$, Kawahara $H$, Mita $K$, et al. A case of melanosis duodeni. Nihon Shokakibyo Gakkai Zasshi. 1996;93(3):18590. Japanese. PMid:8721114.

22. Pueblitz S, Squires RH, Timmons CF. Pseudomelanosis duodeni in an adolescent male: case report and review of the literature. Pediatr Pathol Lab Med. 1997;17(1):115-23. http://dx.doi.org/10.1080/107710497175074

23. Fanning PA, Cooper JE, Roberts-Thomson IC. Images in gastroenterology. Duodenal melanosis. J Gastroenterol Hepatol. 1998;13(1):13. PMid:9737565. http://dx.doi. org/10.1111/j.1440-1746.1998.tb00538.x

24. Kuo YC, Lee PH, Lo TH. Melanosis duodeni: a case report. Endoscopy. 1999;31(6):S51. PMid:10494704.

25. Carmona-Sanchez R, Caballero-Mendoza E, CachafeiroVilar M. Duodenal pseudomelanosis. Rev Gastroenterol Mex. 1999;64(2):92-4. Spanish. PMid:10532135.

26. Arguedas MR, Lazenby A, Wilcox CM. Pseudomelanosis duodena. Gastrointest Endosc. 2000;52(6):753. PMid:11115910. http://dx.doi.org/10.1067/mge.2000.110739

27. Cheng CL, Chen PC, Chen TC. Pseudomelanosis duodeni: case report. Chang Gung Med J. 2000;23(6):372-6. PMid:10958041.

28. Treeprasertsuk S, Thong-Ngam D, Suwangool P, Kullavanijaya P. Pseudomelanosis duodeni: association with hypertension and chronic renal failure: case report. J Med Assoc Thai. 2000;83(8):964-8. PMid:10998854.

29. Weinstock LB, Katzman D, Wang HL. Pseudomelanosis of stomach, duodenum, and jejunum. Gastrointest Endosc. 2003;58(4):578. http://dx.doi.org/10.1067/S00165107(03)01874-1

30. Cantu JA, Adler DG. Pseudomelanosis duodeni. Endoscopy. 2005;37(8):789. PMid:16032511. http://dx.doi. org/10.1055/s-2005-870144

31. Koulaouzidis A, Habib S, Moschos J. Pseudomelanosis duodeni. Indian J Gastroenterol. 2008;27(3):134. PMid:18787289.

32. Yen HH, Chen YY, Soon MS. Pseudomelanosis duodeni: an unusual finding from upper gastrointestinal endoscopy. Clin
Gastroenterol Hepatol. 2009; 7(11):e68. PMid:19665586. http://dx.doi.org/10.1016/j.cgh.2009.07.028

33. Yun L. Education and Imaging. Gastrointestinal: pseudomelanosis duodeni. J Gastroenterol Hepatol. 2010; 25(2):427. PMid:20136990. http://dx.doi. org/10.1111/j.1440-1746.2009.06177.x

34. Krier K, Henderson JB, Bocklage T, Rajput A. Duodenal pseudomelanosis. Surgery [Internet]. 2010 [Epub ahead of print; cited 2011 Nov 29]. http://dx.doi.org/10.1016/j. surg.2010.08.008

35. Kakati B, Krishna S, Sharma S, Rego R. Pseudomelanosis duodeni: a rare finding from upper endoscopy. Dig Endosc. 2011;23(2):201-2. PMid:21429033. http://dx.doi. org/10.1111/j.1443-1661.2010.01060.x

36. Giusto D, Jakate S. Pseudomelanosis duodeni: associated with multiple clinical conditions and unpredictable iron stainability - a case series. Endoscopy. 2008;40(2):165-7. PMid:18253910. http://dx.doi.org/10.1055/s-2007-995472

37. Fisher SE, Kahn E, Ellis D. Melanosis duodeni in a child with congenital hepatic fibrosis and renal failure. J Pediatr Gastroenterol Nutr. 1983;2(3):567-9. PMid:6620063. http:// dx.doi.org/10.1097/00005176-198302030-00029

38. Sharp JR, Insalaco SJ, Johnson LF. "Melanosis" of the duodenum associated with a gastric ulcer and folic acid deficiency. Gastroenterology. 1980. p. 366-9.

39. Kibria R, Ali SA, Akram S. Pseudomelanosis ilei associated with ingestion of oral iron therapy. Endoscopy. 2010;42(Suppl 2):E243-4. http://dx.doi. org/10.1055/s-0030-1255603

40. Kibria R, Barde CJ. Pseudomelanosis of the stomach. Endoscopy. 2010;42 (Suppl 2):E60. PMid:20157892. http:// dx.doi.org/10.1055/s-0029-1243871

41. Ghadially FN, Walley VM. Melanoses of the gastrointestinal tract. Histopathology. 1994;25(3):197-207. PMid:7821887.

42. Meguro R, Asano Y, Odagiri S, Li C, Iwatsuki H, Shoumura $\mathrm{K}$. Nonheme-iron histochemistry for light and electron microscopy: a historical, theoretical and technical review. Arch Histol Cytol. 2007;70(1):1-19. PMid:17558140. http:// dx.doi.org/10.1679/aohc.70.1

43. Kaplan MR, Knittel DR, Lawson P, Schafer TW. Panenteric melanosis: an ominous endoscopic finding. Gastrointest Endosc. 2005;61(6):762-5. http://dx.doi.org/10.1016/ S0016-5107(04)02783-X

44. Kim J, Hwang JK, Choi WS, et al. Pseudomelanosis ilei associated with ingestion of charcoal: case report and review of literature. Dig Endosc. 2010;22(1):56-8. PMid:20078667. http://dx.doi.org/10.1111/j.1443-1661.2009.00919.x

45. Piesman M, Tsuchida A. Pseudomelanosis duodeni resolution with discontinuation of oral iron therapy. Am J Gastroenterol. 2002;97(9):S179. http://dx.doi.org/10.1016/ S0002-9270(02)05025-6 


\section{Conflict of interest: None}

Submitted on: $17^{\text {th }}$ November 2011

Accept on: 23 ${ }^{\text {rd }}$ November 2011

Correspondence: Serviço de Anatomia Patológica

Av. Prof. Lineu Prestes, 2565 - Cidade Universitária - São Paulo - SP - Brazil CEP 05508-900 - Phone: +55 (11) 3091-9379

E-mail: aloisiosilva@hu.usp.br 